\title{
TURNAROUND LEADERSHIP FOR SCHOOL SUSTAINABILITY
}

A substantial body of research literature has indicated school principals are critical to overall school improvement (Heck \& Hallinger, 2014; Jones, et al., 2015; Sleegers et al., 2014; Thoonen et al., 2011). However, improving the fortunes of low-performing schools remains a major concern and challenge in many education systems (Meyers \& Darwin, 2017). Research into turnaround school has been undertaken predominantly in the Western context, particularly in the United States, United Kingdom (Harris et al., 2018), Australia, Canada, England, and Sweden (Liu, 2020). However, research in developing countries remains relatively limited.

The term 'school turnaround' remains elusive (Stuit, 2012) and there is "no single definition of school turnaround exists" (Hochbein \& Mahone, 2017, p. 15). The term turnaround is generally referred as low performing schools that have significantly improved and transformed their challenging circumstances and student academic achievements into high performing schools (Chapman \& Muijs, 2013). "While the research is clear on what an effective school should look like, there is considerably less research, let alone consensus, on the process by which a low performing school becomes a high performing school" (Murphy \& Meyers, 2008, p. 252).

The term "turnaround" itself is goal-directed in its usage. Leading writers describes it as helping poor and minority students in declining schools, reach their potential by developing a safe and nurturing educational environment (Leithwood \& Strauss, 2008; Fullan, 2005). Recent research has found that turnaround schools are mostly affected by communities that disadvantaged and living in poverty (Reyes \& Garcia, 2014). School decline is commonly associated with a complex range of factors including poor facilities, poor leadership (Harris, et al., 2018), limited resources and funds (Duke \& Jacobson, 2011). Therefore, society has a moral obligation to identify and reverse the fortunes of these schools, as all children in these communities, have a right to high quality education (Harold, Burbach, Alfred \& Butler, 2005).

The right turnaround principal makes a difference (Meyers \& Hambrick Hitt, 2017) to what has been described as a 'wicked problem' (Harris, Leithwood \& Strauss, 2010). Turnaround is a 'wicked problem' as it has the potential to return unless the school is successfully led through turnaround (Duke, 2010) ultimately ensuring its sustainable success (Hargreaves \& Fink, 2006). In addition, sustainability is most likely to be achieved if the initiatives of turnaround leaders are anchored in school improvement practices and strategies (Hargreaves \& Fink, 2006). Day (2014) cautions there are no 'quick fixes' to achieve sustainable change and such change will take time. It is widely agreed that five to eight years of support is needed to ensure sustained change in student performance (Day et al., 2010; Fullan, 2007). In addition, the capacity to balance school resources with rising expectations sits at the centre of this consideration.

Therefore, research literatures suggest some consistent strategies to ensure turnaround schools' sustainability. For example, the implementation of accountability measures (Butler, 2012), careful monitoring of teachers' professional development, encourage parent participation (Liu, 2020), changing the school communities' perceptions and beliefs (Fullan, 2010), and a combination of 'top down' and 'bottom up' change (Fullan, 2007). Interestingly, these strategies are strongly linked to strong school leadership. Thus, learning more about how principals are going about their 
work to lead rapid school improvement within the systems context is critical to ensuring the leadership moves necessary to change trajectories.

\section{REFERENCES}

Chapman, C. \& Muijs, D. (2013) Collaborative school turnaround: A study of the impact of school federations on student outcomes. Leadership and Policy in Schools, 12(3), 200-226.

Day, C. (2014). Sustaining the turnaround: What capacity means in practice. Revista Iberoamericana sobre Calidad, Eficacia y Cambio en Educacion, 12(5), 9-20.

Fullan, M. (2005). Turnaround leadership. The Educational Forum. 69 (2), 174-181.

Hargreaves, A., \& Fink, D. (2006). Sustainable leadership. San Francisco: Jossey-Bass.

Harold, J., Burbach, R., Alfred, R., \& Butler, I. (2005). Turnaround principals: An unmistakable conclusion: Site-level success stems from superintendent support. The School Administrator, 1-8.

Harris, A., Leithwood, K., \& Strauss, T. (2010). Leading school turnaround: How successful leaders transform low performing schools. San Francisco: JosseyBass.

Harris, A., Jones, M., Ismail, N., Adams, D., \& Sumintono, B (2018). Leading turnaround and improvement in low performing schools in Malaysia and Indonesia. In C. Meyers \& M. Darwin (Eds.), International Perspectives on Leading LowPerforming Schools (pp.267-287). IAP-Information Age Publishing, Inc.

Heck, R. H., \& Hallinger, P. (2014). Modeling the effects of school leadership on teaching and learning over time. Journal of Educational Administration, 52(5), 653-681.

Hochbein, C and Mahone, A. (2017). The Failure Fallacy: Examining the rate of school turnaround. In C.V. Meyers \& M.J. Darwin (Eds.), Enduring myths that inhibit school turnaround. Charlotte, NC: Information Age.

Jones, M., Adams, D., Hwee Joo, M. T., Muniandy, V., Perera, C. J., \& Harris, A. (2015). Contemporary challenges and changes: principals' leadership practices in Malaysia. Asia Pacific Journal of Education, 35(3), 353-365.

Leithwood, K., \& Strauss, T. (2008). Turnaround schools and the leadership they require. Retrieved from http://www.cea-ace.ca/sites/cea-ace.ca/files/cea2008- turnaround-schools.pdf

Liu, P. (2020). Understanding turnaround leadership research: Continuity and change (2009-2016). Educational Management Administration \& Leadership, 48(1), 624.

Meyers, C. V., \& Darwin, M. J. (Eds.). (2017). Enduring myths that inhibit school turnaround, Charlotte, NC: Information Age.

Meyers, C. V., \& Hambrick Hitt, D. (2017). School turnaround principals: What does initial research literature suggest they are doing to be successful?. Journal of Education for Students Placed at Risk (JESPAR), 22(1), 38-56.

Murphy, M., \& Meyers, C. (2008). Turning around failing schools: leadership lessons from the organisational sciences. Thousand Oakes, California: Corwin Press.

Sleegers, P., Thoonen, E., Oort, F.J. and Peetsma, T. (2014). Changing classroom practices: the role of school-wide capacity for sustainable improvement. Journal of Educational Administration, 52 (5), 617-652.

Stuit, D. (2012). Turnaround and closure rates in the charter and district sectors. Journal of Education for Students Placed at Risk (JESPAR), 17(1-2), 40-54.

Thoonen, E. E., Sleegers, P. J., Oort, F. J., \& Peetsma, T. T. (2012). Building school-wide capacity for improvement: The role of leadership, school organizational 
conditions, and teacher factors. School Effectiveness and School Improvement, 23(4), 441-460.

Donnie Adams

Editor of International Online Journal of Educational Leadership Faculty of Education, University of Malaya donnieadams@um.edu.my 